\title{
Synthesis of Polystyrene and Poly(alkyl methacrylate)s Having Photochromic Dithienylethene Pendant Groups
}

\author{
Hisataka NAKASHIMA and Masahiro IRIE* \\ Department of Molecular Engineering, Graduate School of Engineering Sciences, Kyushu University, \\ Kasugakoen 6-1, Kasuga, Fukuoka 816-8580, Japan \\ * Department of Chemistry and Biochemistry, Graduate School of Engineering, \\ Kyushu University and CREST, Japan Science and Technology Corporation \\ Hakozaki 6-10-1, Higashi-ku, Fukuoka 812-8581, Japan
}

(Received May 26, 1998)

\begin{abstract}
Polystyrene, poly(ethyl methacrylate), and poly(isopropyl methacrylate) having 1-(2-methoxy-1-benzothiophen-3-yl)-2-\{2,4-dimethyl-5-[4-(4-carbonyloxybutyl)phenyl]thiophen-3-yl\}perfluorocyclopentenes were synthesized. Photochemical conversion from open-ring to closed-ring forms of the dithienylethenes was $8-18 \%$ lower than the conversion of the chromophore mixed in the same matrix. Although no appreciable difference was observed in the photostationary conversion below and above the glass transition temperature $\left(T_{\mathrm{g}}\right)$ in polystyrene and poly(ethyl methacrylate), the conversion in poly(isopropyl methacrylate) increased above $T_{\mathrm{g}}$.

KEY WORDS Photochromism/Dithienylethene/Polystyrene/Poly(ethyl methacrylate)/Poly(isopropyl methacrylate) / Photoconversion / Activation Energy / Glass Transition Temperature /
\end{abstract}

Various types of photochromic compounds have been so far attempted to apply to optoelectronic devices, such as optical memory and optical switching. ${ }^{1-14}$ Among the compounds diarylethenes having heterocyclic aryl groups are the most promising photochromic compounds for the application because of their fatigue resistant and thermally irreversible properties. ${ }^{1}$ When we use photochromic compounds for optoelectronic devices, they should be dispersed in polymer matrices by mixing or chemical binding to the polymers.

In the present study, we synthesized polystyrene, poly(ethyl methacrylate), and poly(isopropyl methacrylate) having 1-(2-methoxy-1-benzothiophen-3-yl)-2-\{2,4dimethyl-5-[4-(4-carbonyloxybutyl)phenyl]thiophen-3yl)perfluorocyclopentenes (DE) in the pendant groups. Photoreactivity below and above $T_{\mathrm{g}}$, and temperature dependence of photoisomerization rate in coloring and bleaching processes were examined.

\section{EXPERIMENTAL}

\section{Materials}

Solvents for the reactions were used after distillation. Commercially available reagents were used without further purification. Compounds 1 and $\mathbf{4}$ were synthesized according to a method described elsewhere. ${ }^{15}$

\section{Synthesis of Dithienylethene 3}

4-[4-[4-[2-(2-Methoxy-1-benzothiophen-3-yl)-3,3,4, 4,5,5-hexafluorocyclopentenyl]-3,5-dimethylthien-2-yl]phenyl]butanol (2). Synthesis of primary alcohol by hydroboration-oxidation reaction of olefin was referred to the method of Brown et al. ${ }^{16}$ To a stirred anhydrous tetrahydrofuran (THF) solution $\left(11.5 \mathrm{~cm}^{3}\right)$ containing $6.5 \mathrm{~cm}^{3}$ of borane-THF complex $(6.5 \mathrm{mmol}, 1 \mathrm{M}$ solution) was added a THF solution $\left(7 \mathrm{~cm}^{3}\right)$ containing compound 1 (550 mg, $0.951 \mathrm{mmol})$ under argon atmosphere, and refluxed for $16 \mathrm{~h}$. The solution was cooled to room temperature, and $4.8 \mathrm{~cm}^{3}$ of ethanol were added. The reaction mixture was oxidized with $6 N$ sodium hydroxide aqueous solution $\left(1.6 \mathrm{~cm}^{3}\right)$ and $30 \%$ hydrogen peroxide $\left(3.2 \mathrm{~cm}^{3}\right)$ for $1 \mathrm{~h}$ at $55^{\circ} \mathrm{C}$. The reaction mixture was diluted with ether, saturated with potassium carbonate $(2.1 \mathrm{~g})$, and filtered. The filtrate was evaporated and purified by column chromatography on silica gel (ethyl acetate/hexane $=1 / 7$ ) to give $349 \mathrm{mg}$ of 4 -[4-[4[2-(2-methoxy-1-benzothiophen-3-yl)-3,3,4,4,5,5-hexafluorocyclopentenyl]-3,5-dimethylthien-2-yl]phenyl]butanol (2) in $62 \%$ yield.

2: Colorless viscous oil; ${ }^{1} \mathrm{H}$ NMR $\left(\mathrm{CDCl}_{3}\right): \delta=1.45$ $1.78\left(\mathrm{~m}, 4 \mathrm{H}, \mathrm{Ar}-\mathrm{C}-\mathrm{CH}_{2}-\mathrm{CH}_{2}-\mathrm{C}-\right), 2.02$ (s, 3H, $\left.\mathrm{Ar}-\mathrm{CH}_{3}\right), 2.22\left(\mathrm{~s}, 3 \mathrm{H}, \mathrm{Ar}-\mathrm{CH}_{3}\right), 2.61(\mathrm{t}, J=6 \mathrm{~Hz}, 2 \mathrm{H}$, $\left.\mathrm{Ar}-\mathrm{CH}_{2}-\mathrm{C}-\mathrm{C}-\mathrm{C}-\right), 3.65(\mathrm{t}, J=6 \mathrm{~Hz}, 2 \mathrm{H}, \mathrm{Ar}-\mathrm{C}-\mathrm{C}-\mathrm{C}-$ $\left.\mathrm{CH}_{2}-\right), 3.79\left(\mathrm{~s}, 3 \mathrm{H}, \mathrm{Ar}-\mathrm{OCH}_{3}\right), 7.10-7.38(\mathrm{~m}, 6 \mathrm{H}$, $\mathrm{Ar}-\mathrm{H}$ ), 7.59 (d, $J=8 \mathrm{~Hz}, 2 \mathrm{H}, \mathrm{Ar}-\mathrm{H})$; IR (KBr): 3400 (OH) $\mathrm{cm}^{-1}$; MS (70 eV): $m / z 596\left(\mathrm{M}^{+}\right)$.

1-(2-Methoxy-1-benzothiophen-3-yl)-2-\{2,4-dimethyl5-[4-(4-methacryloyloxybutyl)phenyl] thien-3-yl $\}$ perfluorocyclopentene (3). To a stirred sodium hydride $(53.4 \mathrm{mg}$, $1.34 \mathrm{mmol})$ was added a THF solution $\left(10 \mathrm{~cm}^{3}\right)$ containing compound 2 ( $166 \mathrm{mg}, 0.278 \mathrm{mmol}$ ) under argon atmosphere, and stirred for $1 \mathrm{~h}$ at room temperature. A THF solution $\left(2 \mathrm{~cm}^{3}\right)$ containing methacrylic anhydride ( $140 \mathrm{mg}, 0.908 \mathrm{mmol}$ ) was added to the reaction solution and stirred for $7 \mathrm{~h}$ at $50^{\circ} \mathrm{C}$. The reaction mixture was cooled to room temperature, acidified with $2 \mathrm{~N}$ hydrochloric acid, and extracted with ether. The organic layer was washed with brine, dried over magnesium sulfate, filtered and evaporated. The residue was purified by column chromatography on silica gel (ethyl acetate/ hexane $=1 / 7)$ to give $117 \mathrm{mg}$ of 1 -(2-methoxy-1-benzothiophen-3-yl)-2-\{2,4-dimethyl-5-[4-(4-methacryloyloxybutyl)phenyl] thien-3-yl\}perfluorocyclopentene (3) in $63 \%$ yield.

3: Colorless viscous oil; ${ }^{1} \mathrm{H}$ NMR $\left(\mathrm{CDCl}_{3}\right): \delta=1.65$ $1.78\left(\mathrm{~m}, 4 \mathrm{H}, \mathrm{Ar}-\mathrm{C}-\mathrm{CH}_{2}-\mathrm{CH}_{2}-\mathrm{C}-\mathrm{O}\right), 1.95(\mathrm{~s}, 3 \mathrm{H}$, $\left.\mathrm{C}=\mathrm{C}\left(\mathrm{CH}_{3}\right)-\mathrm{C}=\mathrm{O}\right), 2.07\left(\mathrm{~s}, 3 \mathrm{H}, \mathrm{Ar}-\mathrm{CH}_{3}\right), 2.27(\mathrm{~s}, 3 \mathrm{H}$, $\left.\mathrm{Ar}-\mathrm{CH}_{3}\right), 2.66\left(\mathrm{~m}, 2 \mathrm{H}, \mathrm{Ar}-\mathrm{CH}_{2}-\mathrm{C}-\mathrm{C}-\mathrm{C}-\mathrm{O}\right), 3.80(\mathrm{~s}, 3 \mathrm{H}$, $\left.\mathrm{Ar}-\mathrm{OCH}_{3}\right), 4.18\left(\mathrm{~m}, 2 \mathrm{H}, \mathrm{Ar}-\mathrm{C}-\mathrm{C}-\mathrm{C}-\mathrm{CH}_{2}-\mathrm{O}\right), 5.55(\mathrm{~s}$, $\left.1 \mathrm{H}, \mathrm{CH}_{2}=\mathrm{C}-(\mathrm{C})-\mathrm{C}=\mathrm{O}\right), 6.09\left(\mathrm{~s}, 1 \mathrm{H}, \mathrm{CH}_{2}=\mathrm{C}(\mathrm{C})-\right.$ 
$\mathrm{C}=\mathrm{O}), 7.10-7.42(\mathrm{~m}, 6 \mathrm{H}, \mathrm{Ar}-\mathrm{H}), 7.58-7.68(\mathrm{~m}, 2 \mathrm{H}$ $\mathrm{Ar}-\mathrm{H})$; IR (KBr): $1700 \mathrm{~cm}^{-1}(\mathrm{C}=\mathrm{O}) ; \mathrm{MS}(70 \mathrm{eV}): \mathrm{m} / \mathrm{z}$ $664\left(\mathrm{M}^{+}\right)$; Anal. Calcd for $\mathrm{C}_{34} \mathrm{H}_{30} \mathrm{~F}_{6} \mathrm{O}_{3} \mathrm{~S}_{2}$ : C, 61.44\%; $\mathrm{H}, 4.55 \%$. Found: $\mathrm{C}, 61.48 \%$; H, 4.69\%.

\section{Synthesis of Polymers 5-10}

Copolymerization of Dithienylethene $\mathbf{3}$ with Styrene (5). To a benzene solution $\left(1.5 \mathrm{~cm}^{3}\right)$ containing compound 3 (20 $\mathrm{mg}, 0.030 \mathrm{mmol})$ and styrene $(157 \mathrm{mg}, 1.51 \mathrm{mmol})$ was added 2,2'-azobisisobutyronitrile (AIBN) $(8.9 \mathrm{mg}, 0.054$ mmol) and bubbled with nitrogen for $5 \mathrm{~min}$ to remove dissolving oxygen. The mixture solution was heated for $2 \mathrm{~h}$ at $60-70^{\circ} \mathrm{C}$. The reaction mixture was cooled to room temperature and purified by reprecipitation with methanol to give $42.1 \mathrm{mg}$ of 5 in $24 \%$ yield.

5: Colorless solid; ${ }^{1} \mathrm{H}$ NMR $\left(\mathrm{CDCl}_{3}\right): \delta=0.88-1.16$ $\left(\mathrm{m},-\mathrm{C}-\mathrm{C}\left(\mathrm{CH}_{3}\right)-\mathrm{C}=\mathrm{O}\right), 1.20-2.00\left(\mathrm{~m},-\mathrm{CH}_{2}-\mathrm{C}(\mathrm{Ar})^{-}\right.$, $\left.\mathrm{Ar}-\mathrm{C}-\mathrm{CH}_{2} \mathrm{CH}_{2}-\mathrm{C}-,-\mathrm{C}-\mathrm{CH}(\mathrm{Ar})-,-\mathrm{CH}_{2}-\mathrm{C}(\mathrm{C})-\mathrm{C}=\mathrm{O}\right)$, $2.06\left(\mathrm{~s}, \mathrm{Ar}-\mathrm{CH}_{3}\right), 2.25\left(\mathrm{~s}, \mathrm{Ar}-\mathrm{CH}_{3}\right), 3.76\left(\mathrm{~s}, \mathrm{Ar}-\mathrm{OCH}_{3}\right)$, $6.24-6.78\left(\mathrm{~m}, \mathrm{H}_{2}, \mathrm{H}_{6}\right.$ of styrene $), 6.87-7.30(\mathrm{~m}$, $\mathrm{H}_{3}-\mathrm{H}_{5}$ of styrene), $7.58-7.66(\mathrm{~m}, \mathrm{Ar}-\mathrm{H})$; IR $(\mathrm{KBr})$ : $3040(\mathrm{C}-\mathrm{H}$ of $\mathrm{Ar}), 1730(\mathrm{C}=\mathrm{O}), 1605,1495,1460(\mathrm{C}=\mathrm{C}$ of $\mathrm{Ar}), 760(\mathrm{C}-\mathrm{H}$ of $\mathrm{Ar}), 700(\mathrm{C}=\mathrm{C}$ of $\mathrm{Ar}) \mathrm{cm}^{-1}$.

Copolymerization of Dithienylethene 3 with Ethyl Methacrylate (6). Reaction of compound $3(17.5 \mathrm{mg}, 0.0263$ $\mathrm{mmol})$ and ethyl methacrylate $(151 \mathrm{mg}, 1.32 \mathrm{mmol})$ was performed by the same procedure as for $\mathbf{5}$. The crude product was purified by reprecipitation with methanol and water to give $21.2 \mathrm{mg}$ of 6 in $13 \%$ yield.

6: Colorless solid; ${ }^{1} \mathrm{H}$ NMR $\left(\mathrm{CDCl}_{3}\right): \delta=0.68-1.42$ $\left(\mathrm{m},-\mathrm{C}-\mathrm{C}\left(\mathrm{CH}_{3}\right)-\mathrm{C}=\mathrm{O},-\mathrm{C}-(=\mathrm{O})-\mathrm{O}-\mathrm{C}-\mathrm{CH}_{3}\right), 1.42-$ $1.75\left(\mathrm{~m}, \mathrm{Ar}-\mathrm{C}-\mathrm{CH}_{2} \mathrm{CH}_{2}-\mathrm{C}-\right)$, 1.75-2.00 (m, $-\mathrm{CH}_{2}-\mathrm{C}-$ $(\mathrm{C})-\mathrm{C}=\mathrm{O}), 2.05$ (s, $\left.\mathrm{Ar}-\mathrm{CH}_{3}\right), 2.20\left(\mathrm{~s}, \mathrm{Ar}-\mathrm{CH}_{3}\right)$, $2.55-2.65$ (m, Ar- $\mathrm{CH}_{2}-\mathrm{C}-\mathrm{C}-\mathrm{C}-$ ), 3.79 (s, $\mathrm{Ar}-\mathrm{OCH}_{3}$ ), $3.85-4.20\left(\mathrm{~m},-\mathrm{C}(=\mathrm{O})-\mathrm{O}-\mathrm{CH}_{2}-\mathrm{C}\right), 7.10-7.35(\mathrm{~m}$, Ar-H), 7.55-7.63 (m, Ar-H); IR (KBr): $3000(\mathrm{C}-\mathrm{H}$ of Alkane $), 1730(\mathrm{C}=\mathrm{O}), 1180-1150(\mathrm{C}-\mathrm{C}(=\mathrm{O})-\mathrm{O}), 1030$ (O-C-C) $\mathrm{cm}^{-1}$.

Copolymerization of Dithienylethene $\mathbf{3}$ with Isopropyl Methacrylate (7). Reaction of compound 3 (20 mg, $0.030 \mathrm{mmol}$ ) and isopropyl methacrylate $(194 \mathrm{mg}, 1.51$ mmol) was performed as for $\mathbf{5}$. The crude product was purified by reprecipitation with methanol and water to give $118.3 \mathrm{mg}$ of 7 in $55 \%$ yield.

7: Colorless solid; ${ }^{1} \mathrm{H}$ NMR $\left(\mathrm{CDCl}_{3}\right): \delta=0.76-1.41$ $\left(\mathrm{m},-\mathrm{C}-\mathrm{C}\left(\mathrm{CH}_{3}\right)-\mathrm{C}=\mathrm{O},-\mathrm{C}-(=\mathrm{O})-\mathrm{O}-\mathrm{C}-\mathrm{CH}_{3}\right), 1.62-$ $2.10\left(\mathrm{~m}, \mathrm{Ar}-\mathrm{C}-\mathrm{CH}_{2} \mathrm{CH}_{2}-\mathrm{C}-,-\mathrm{CH}_{2}-\mathrm{C}(\mathrm{C})-\mathrm{C}=\mathrm{O}\right), 2.05$ $\left(\mathrm{s}, \mathrm{Ar}-\mathrm{CH}_{3}\right), 2.25\left(\mathrm{~s}, \mathrm{Ar}-\mathrm{CH}_{3}\right), 2.55-2.71\left(\mathrm{~m}, \mathrm{Ar}-\mathrm{CH}_{2}-\right.$ $\mathrm{C}-\mathrm{C}-\mathrm{C}-), 3.81\left(\mathrm{~s}, \mathrm{Ar}-\mathrm{OCH}_{3}\right), 4.72-4.98(\mathrm{~m},-\mathrm{C}(=\mathrm{O})-$ O-CH-C), $7.15-7.69$ (m, Ar-H); IR (KBr): 2980 (C-H of Alkane), $1730(\mathrm{C}=\mathrm{O}), 1180-1150(\mathrm{C}-\mathrm{C}(=\mathrm{O})-\mathrm{O})$, 1110 (O-[secondary alkyl]) $\mathrm{cm}^{-1}$.

Polymerization of Styrene (8). To a benzene solution $\left(5 \mathrm{~cm}^{3}\right)$ containing styrene $(1.0 \mathrm{~g}, 9.6 \mathrm{mmol})$ was added AIBN (50 mg, $0.30 \mathrm{mmol})$ and bubbled with nitrogen for $5 \mathrm{~min}$ to remove the dissolving oxygen. The mixture solution was heated for $2 \mathrm{~h}$ at $60-70^{\circ} \mathrm{C}$. The reaction mixture was cooled to room temperature and purified by reprecipitation with methanol to give $0.27 \mathrm{~g}$ of $\mathbf{8}$ in $27 \%$ yield.

8: Colorless solid; ${ }^{1} \mathrm{H}$ NMR $\left(\mathrm{CDCl}_{3}\right): \delta=1.25-1.65$ $\left(\mathrm{m}, \quad-\mathrm{CH}_{2}-\mathrm{C}(\mathrm{Ar})-\right), \quad 1.65-2.10$ (m, $\left.-\mathrm{C}-\mathrm{CH}(\mathrm{Ar})-\right)$, $6.30-6.75\left(\mathrm{~m}, \mathrm{H}_{2}, \mathrm{H}_{6}\right.$ of styrene), 6.90-7.30 (m,
$\mathrm{H}_{3}-\mathrm{H}_{5}$ of styrene); IR (KBr): 3040 (C-H of Ar), 1605 , 1495, $1460(\mathrm{C}=\mathrm{C}$ of $\mathrm{Ar}), 760(\mathrm{C}-\mathrm{H}$ of $\mathrm{Ar}), 700(\mathrm{C}=\mathrm{C}$ of $\mathrm{Ar}) \mathrm{cm}^{-1}$.

Polymerization of Ethyl Methacrylate (9). The polymerization of ethyl methacrylate $(1.0 \mathrm{~g}, 8.8 \mathrm{mmol})$ was performed as for 8 . The crude product was purified by reprecipitation with methanol and water to give $41.5 \mathrm{mg}$ of 9 in $42 \%$ yield.

9: Colorless solid; ${ }^{1} \mathrm{H}$ NMR $\left(\mathrm{CDCl}_{3}\right): \delta=0.82-1.40$ $\left(\mathrm{m},-\mathrm{C}-\mathrm{C}\left(\mathrm{CH}_{3}\right)-\mathrm{C}=\mathrm{O},-\mathrm{C}-(=\mathrm{O})-\mathrm{O}-\mathrm{C}-\mathrm{CH}_{3}\right), 1.76-$ $2.10\left(\mathrm{~m},-\mathrm{CH}_{2}-\mathrm{C}(\mathrm{C})-\mathrm{C}=\mathrm{O}\right), 3.98-4.17(\mathrm{~m},-\mathrm{C}(=\mathrm{O})$ $\left.\mathrm{O}-\mathrm{CH}_{2}-\mathrm{C}\right)$; IR (KBr): $3000(\mathrm{C}-\mathrm{H}$ of Alkane), 1730 $(\mathrm{C}=\mathrm{O}), \quad 1180-1150 \quad(\mathrm{C}-\mathrm{C}(=\mathrm{O})-\mathrm{O}), 1030 \quad(\mathrm{O}-\mathrm{C}-\mathrm{C})$ $\mathrm{cm}^{-1}$.

Polymerization of Isopropyl Methacrylate (10). The polymerization of isopropyl methacrylate $(1.0 \mathrm{~g}, 7.8$ mmol) was performed as for $\mathbf{8}$. The crude product was purified by reprecipitation with methanol and water to give $61.7 \mathrm{mg}$ of $\mathbf{1 0}$ in $62 \%$ yield.

10: Colorless solid; ${ }^{1} \mathrm{H}$ NMR $\left(\mathrm{CDCl}_{3}\right): \delta=0.80-1.40$ $\left(\mathrm{m},-\mathrm{C}-\mathrm{C}\left(\mathrm{CH}_{3}\right)-\mathrm{C}=\mathrm{O},-\mathrm{C}(=\mathrm{O})-\mathrm{O}-\mathrm{C}-\mathrm{CH}_{3}\right), \quad 1.74$ $2.12\left(\mathrm{~m},-\mathrm{CH}_{2}-\mathrm{C}(\mathrm{C})-\mathrm{C}=\mathrm{O}\right), 4.75-5.00(\mathrm{~m},-\mathrm{C}(=\mathrm{O})$ $\mathrm{O}-\mathrm{CH}-\mathrm{C})$; IR (KBr): $2980(\mathrm{C}-\mathrm{H}$ of Alkane), 1730 $(\mathrm{C}=\mathrm{O}), \quad 1180-1150 \quad(\mathrm{C}-\mathrm{C}(=\mathrm{O})-\mathrm{O}), \quad 1110 \quad(\mathrm{O}-[\mathrm{se}-$ condary alkyl]) $\mathrm{cm}^{-1}$.

\section{Film Preparation}

A film sample was prepared by spin-coating toluene solution $\left(0.7-1.1 \mathrm{~cm}^{3}\right)$ containing $20-50 \mathrm{mg}$ polymers possessing dithienylethene pendant groups, or $20-50 \mathrm{mg}$ of polymers and compound $\mathbf{4}$ on suprasil glass plates. Film thickness was $0.2-1.5 \mu \mathrm{m}$. Absorption coefficients of $4 \mathbf{a}$ and $\mathbf{4 b}$ were determined as $2.3 \times 10^{4} \mathrm{~mol}^{-1} \mathrm{dm}^{3}$ $\mathrm{cm}^{-1}$ at $266 \mathrm{~nm}$ and $1.2 \times 10^{4} \mathrm{~mol}^{-1} \mathrm{dm}^{3} \mathrm{~cm}^{-1}$ at $567 \mathrm{~nm}$ in hexane, respectively.

\section{Measurements}

${ }^{1} \mathrm{H}$ NMR spectra were recorded on Varian-Gemin-200 $(200 \mathrm{MHz})$ spectrometer. IR spectra were recorded on a Perkin-Elmer-1600 infrared spectrophotometer. DSC measurements were performed with a Seiko DSC $220 \mathrm{C}$. Film thickness was measured with a Tencor alpha-step 200. Photoirradiation was carried out with a USHIO $1 \mathrm{~kW}$ high pressure mercury lamp. Mercury lines of 366 nm were isolated by passing the light through cutoff filters (Toshiba UV-29 and UV-D36C). The light that passed through cutoff filters (Toshiba UV-29 and O-55) was used as visible light $(\lambda>550 \mathrm{~nm})$. Absorption spectra were recorded on a spectrophotometer (Hitachi, U-3410). Temperature dependence of the absorption spectra was measured with a multi-channel analyzer (Hamamatsu Photonics, PMA-11) connected to an optical microscope (Nikon Optiphot) and personal computer. Temperature was controlled with a hot-stage (Mettler, FP800).

\section{RESULTS AND DISCUSSION}

Compound 3 was synthesized as shown in Scheme 1 and polymerized with styrene (ST), ethyl methacrylate (EMA), or isopropyl methacrylate (PMA) in the presence of AIBN as radical initiator in benzene solutions. Polymers 5 (polystyrene (PS)-dithienylethene (DE)), 6 (poly(ethyl methacrylate) (PEMA)-DE), and 7 (poly(- 


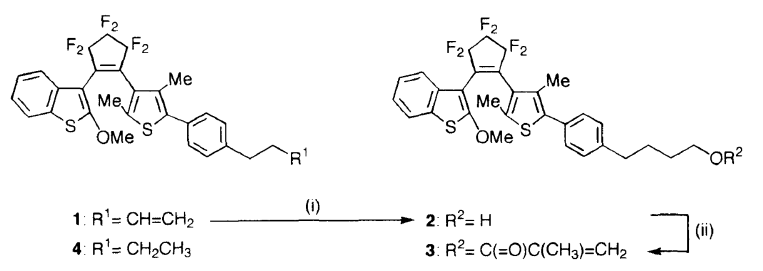

(i) $\mathrm{BH}_{3} \cdot \mathrm{THF} / \mathrm{THF}$, refl., $16 \mathrm{~h} ; 6 \mathrm{~N}-\mathrm{NaOH}_{\mathrm{aq}}, 30 \% \mathrm{H}_{2} \mathrm{O}_{2 \text { aq }}, 55^{\circ} \mathrm{C}, 1 \mathrm{~h}$; $62 \%$. (ii) $\mathrm{NaH}$, methacrylic anhydride $/ \mathrm{THF}, 50^{\circ} \mathrm{C}, 7 \mathrm{~h} ; 63 \%$

Scheme 1.
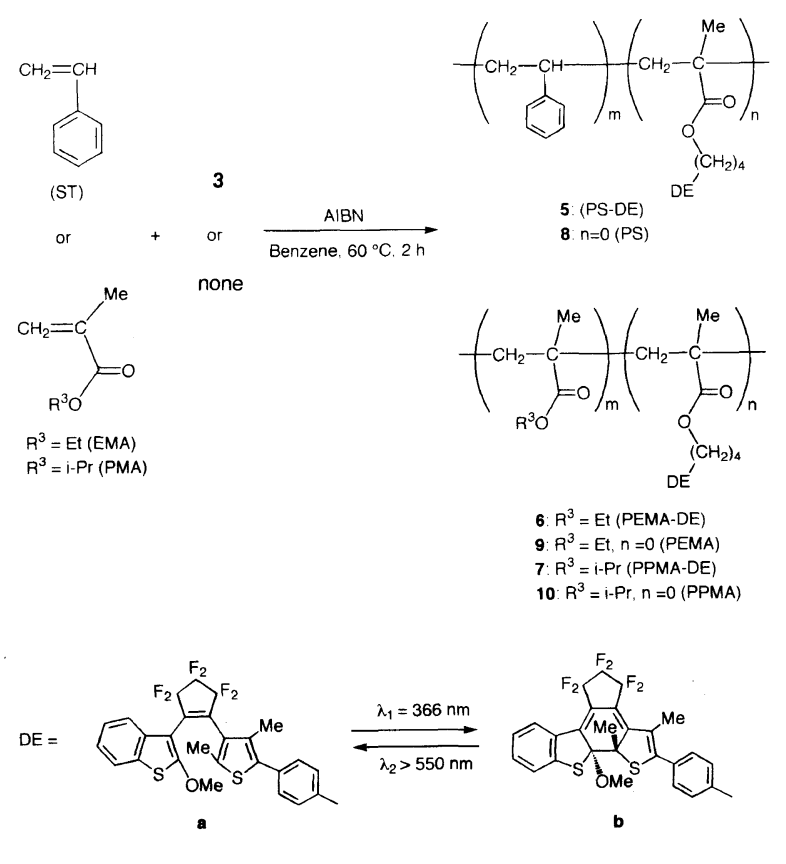

Scheme 2.

isopropyl methacrylate) (PPMA)-DE) were obtained by copolymerization as shown in Scheme 2. Table I shows composition, $T_{\mathrm{g}}$, number-average molecular weight $\left(\bar{M}_{n}\right)$, polydispersity $\left(\bar{M}_{w} / \bar{M}_{n}\right)$ of the polymers 5-7. Polymers 8 (PS), 9 (PEMA), and 10 (PPMA) were also synthesized from the monomers ST, EMA, and PMA, respectively, by the similar manner as shown in Scheme 2 .

Film samples 11C - 13C prepared from polymers 5-7, respectively, showed normal photochromic reactions. Figure 1 shows typical absorption spectral change of $\mathbf{1 3 C}$ by irradiation with $366 \mathrm{~nm}$ light. Upon irradiation with $366 \mathrm{~nm}$ light, the colorless open-ring form a was converted to the purple-blue closed-ring form $\mathbf{b}$, and the purple-blue color disappeared by irradiation with visible $(\lambda>550 \mathrm{~nm})$ light. Similar spectral change was observed for $11 \mathrm{C}$ and $12 \mathrm{C}$.

The conversion of $11 \mathrm{C}-\mathbf{1 3 C}$ from the open-ring to the closed-ring form in the photostationary state by irradiation with $366 \mathrm{~nm}$ light was estimated from the spectral data of the film samples 11D-13D, in which the closed-ring form isomer of $\mathbf{4}$ was mixed in polymers 8 -10, respectively. Figure 2 shows the absorption spectra for 13Da, 13Db, and in the photostationary state by irradiation with $366 \mathrm{~nm}$ light. Similar spectral changes were observed for samples 11D and 12D. Conversion of 13D from the open-ring to the closed-ring form at the photostationary state was determined to be $79 \%$ by
Table I. Data of polymers having dithienylethene pendant groups

\begin{tabular}{|c|c|c|c|c|c|}
\hline \multirow{2}{*}{ No. } & \multirow{2}{*}{ Polymer $^{\mathrm{a}}$} & \multirow{2}{*}{ Composition $^{\mathrm{b}}$} & \multirow{2}{*}{$\frac{T_{\mathrm{g}}}{{ }^{\circ} \mathrm{C}}$} & \multicolumn{2}{|c|}{ Molecular weight ${ }^{c}$} \\
\hline & & & & $10^{-3} \bar{M}_{n}$ & $\bar{M}_{w} / \bar{M}_{n}$ \\
\hline 5 & PS-DE & $19 / 0.6$ & 88 & 5.4 & 1.4 \\
\hline 6 & PEMA-DE & $23 / 1.0$ & 55 & 23.4 & 1.7 \\
\hline 7 & PPMA-DE & $66 / 1.3$ & 31 & 8.2 & 1.7 \\
\hline
\end{tabular}

${ }^{a}$ PS, PEMA, PPMA, and DE denote polystyrene, poly(ethyl methacrylate), poly(isopropyl methacrylate), and dithienylethene, respectively, as shown in Scheme 2. ${ }^{\mathrm{b}}$ Determined by ${ }^{1} \mathrm{H}$ NMR. $\quad{ }^{\mathrm{C}}$ Determined by gel-permeation chromatography using polystyrene as the standard.

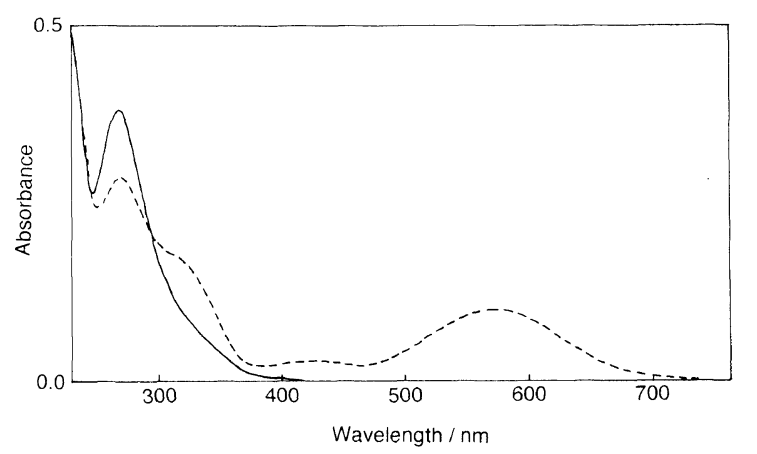

Figure 1. Absorption spectra of film 13Ca (-) and in the photostationary state (---) under irradiation with $366 \mathrm{~nm}$ light.

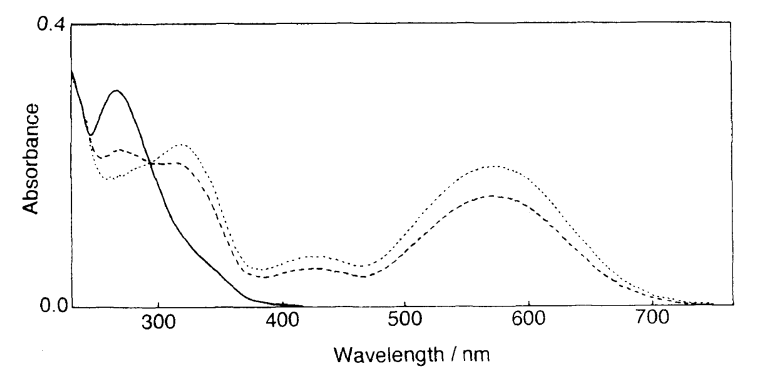

Figure 2. Absorption spectra of film 13Da $(-)$, 13Db $(\cdots \cdots)$, and in the photostationary state (---) under irradiation with $366 \mathrm{~nm}$ light.

comparing absorbance at $573 \mathrm{~nm}$ of the closed-ring form 13Db with photostationary absorbance. Conversion of 13C was calculated to be $67 \%$ based on eq 1 :

$$
\operatorname{Conv}(C)=\operatorname{Conv}(D) \frac{\operatorname{Abs}(C)_{574}^{\prime}}{\operatorname{Abs}(C)_{340}} \frac{\operatorname{Abs}(D)_{340}}{\operatorname{Abs}(D)_{573}^{\prime}}
$$

where $\operatorname{Conv}(C)$ and $\operatorname{Conv}(D)$ are the conversion $(\%)$ of DEs chemically bounded to PPMA, 13C, and DEs mixed in the polymer, 13D, respectively. $\operatorname{Abs}(C)_{574}^{\prime}$ and $\operatorname{Abs}(C)_{340}$ are absorbance at $\lambda_{\max }$ of the closed-ring form in the photostationary state under irradiation with $366 \mathrm{~nm}$ light, and the absorbance at $340 \mathrm{~nm}$ of the open-ring form, respectively. $\operatorname{Abs}(D)_{573}^{\prime}$ and $\operatorname{Abs}(D)_{340}$ denote absorbance at $573 \mathrm{~nm}$ of the photostationary state and at $340 \mathrm{~nm}$ of the open-ring form DEs mixed in the same polymer matrix. Table II summarizes the conversions of six polymer samples, 11C-13D, in the photostationary state together with DE content in the polymers.

Figure 3 shows the normalized absorption intensities at $\lambda_{\max }$ below and above $T_{\mathrm{g}}$ of $11 \mathrm{C}-13 \mathrm{C}$ in the photostationary state. No appreciable difference in the 
Table II. Conversion of polymers containing dithienylethenes

\begin{tabular}{|c|c|c|c|c|}
\hline \multirow{2}{*}{ Sample $^{\mathrm{a}}$} & \multirow{2}{*}{ Materials } & $\lambda_{\max }$ & DE Content & Conv. $^{d}$ \\
\hline & & $\mathrm{nm}$ & $\mathrm{mol} \%$ & $\%$ \\
\hline $11 \mathrm{C}$ & PS-DE & 576 & $3.1^{\mathrm{b}}$ & 61 \\
\hline $11 D$ & 4 in PS & 576 & $4.8^{\mathrm{c}}$ & 69 \\
\hline $12 \mathrm{C}$ & PEMA-DE & 572 & $4.3^{b}$ & 64 \\
\hline 12D & 4 in PEMA & 574 & $2.6^{\mathrm{c}}$ & 82 \\
\hline $13 \mathrm{C}$ & PPMA-DE & 574 & $1.9^{\mathrm{b}}$ & 67 \\
\hline 13D & 4 in PPMA & 573 & $3.2^{\mathrm{c}}$ & 79 \\
\hline
\end{tabular}

${ }^{a} \mathrm{C}$ denotes dithienylethene chemically bounded to polymer, D denotes dithienylethene mixed in polymer. ${ }^{\mathrm{b}}$ Determined by ${ }^{1} \mathrm{H}$ NMR. ${ }^{\mathrm{c}}$ Feed ratio of polymer and dithienylethene when film was prepared. ${ }^{\mathrm{d}}$ Measured at $25^{\circ} \mathrm{C}$.

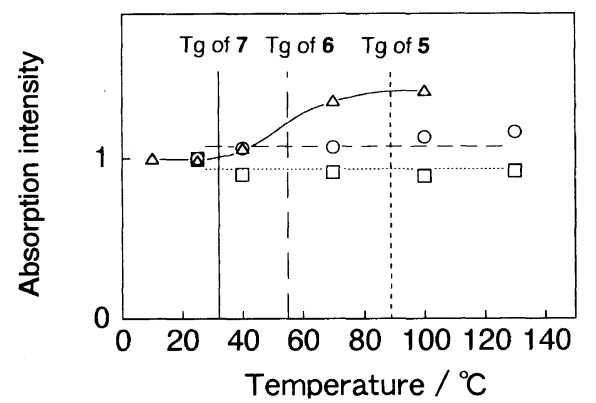

Figure 3. Normalized absorption intensities at $\lambda_{\max }$ of photogenerated

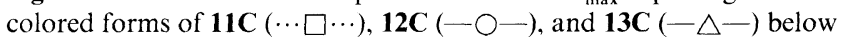
and above the glass transition temperature in the photostationary state under irradiation with $366 \mathrm{~nm}$ light. Intensity at the lowest measuring temperatures was normalized to 1 .

absorption intensities for $11 \mathrm{C}$ and $\mathbf{1 2 C}$ was observed. However, absorption intensity above $T_{\mathrm{g}}$ for $13 \mathrm{C}$ was larger than the value below $T_{\mathrm{g}}$. This indicates that the free volume above $T_{\mathrm{g}}$ in $13 \mathrm{C}$ is more widespread than the one below $T_{\mathrm{g}}$ and rotation of the thienyl groups are allowed above $T_{\mathrm{g}}$. Such free volume change which affects the photoisomerization reaction was not observed for PS and PEMA.

Figures 4 and 5 show the absorption intensity change at $\lambda_{\max }$ for $11 \mathrm{C}-13 \mathrm{C}$ by irradiation with $366 \mathrm{~nm}$ and visible $(\lambda>550 \mathrm{~nm})$ light at $40^{\circ} \mathrm{C}$, respectively. In coloring and bleaching, no appreciable difference was observed among the three samples.

The reversible photoisomerization reaction in Scheme 2 is expressed by eq 2 , where $A$ and $B$ denote the open-ring and the closed-ring forms of DE, respectively. $\Phi_{\mathrm{A} \rightarrow \mathrm{B}}$ and $\Phi_{\mathrm{B} \rightarrow \mathrm{A}}$ are quantum yields for the photoisomerization reactions from $\mathrm{A}$ to $\mathrm{B}$ (coloring) and $\mathrm{B}$ to $\mathrm{A}$ (bleaching), respectively.

$$
\mathrm{A} \underset{\Phi_{\mathrm{B} \rightarrow \mathrm{A}}}{\stackrel{\Phi_{\mathrm{A} \rightarrow \mathrm{B}}}{\rightleftarrows}} \mathrm{B}
$$

When the open-ring isomer with initial concentration $C_{\mathrm{A}}(0)$ is irradiated with $366 \mathrm{~nm}$ light, the formation kinetics of the closed-ring isomer is given as,

$$
\ln \frac{\operatorname{Abs}(\infty)-\operatorname{Abs}(0)}{\operatorname{Abs}(\infty)-\operatorname{Abs}(t)}=2.303 \times 10^{3} I_{0} \varepsilon_{\mathrm{A}} \Phi_{\mathrm{A} \rightarrow \mathrm{B}} \frac{C_{0}}{C_{\mathrm{B}}(\infty)} t
$$

where $\operatorname{Abs}(t)$ is the absorbance at $\lambda_{\max }$ of $\mathrm{B}$ at time $t, I_{0}$ 988

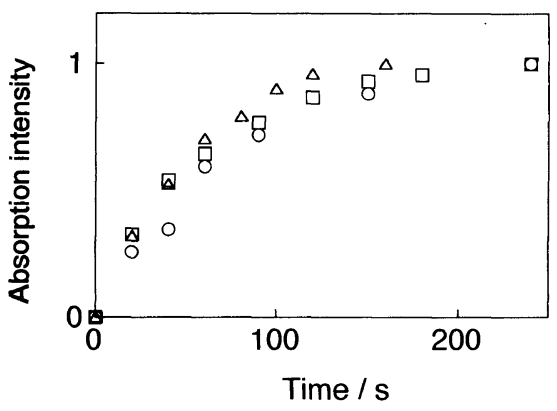

Figure 4. Absorption intensity changes of polymer film samples, 11C $(\square), 12 \mathrm{C}(\bigcirc)$, and $13 \mathrm{C}(\triangle)$ at $\lambda_{\max }$ by irradiation with $366 \mathrm{~nm}$ light at $40^{\circ} \mathrm{C}$.

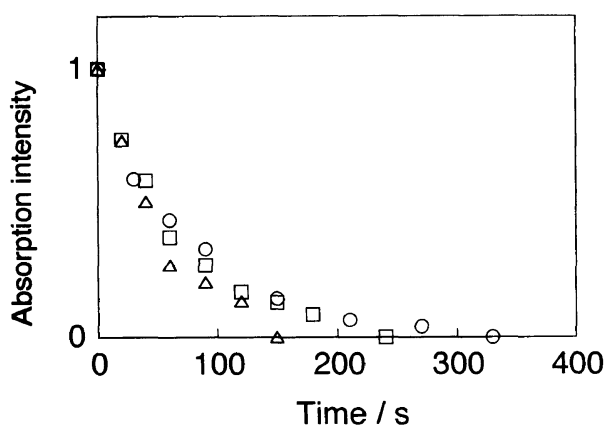

Figure 5. Absorption intensity changes of polymer film samples, 11C $(\square), 12 \mathrm{C}(\bigcirc)$, and $13 \mathrm{C}(\triangle)$ at $\lambda_{\max }$ by irradiation with visible $(\lambda>550 \mathrm{~nm})$ light at $40^{\circ} \mathrm{C}$.

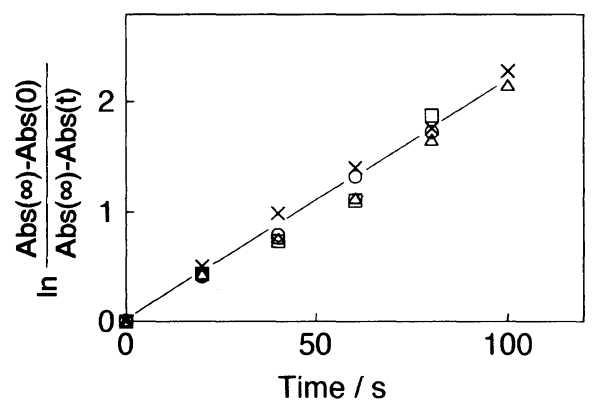

Figure 6. Irradiation time dependence of the left hand side of eq 3 in the coloring process of polymer film sample $13 \mathrm{C}$ at $25^{\circ} \mathrm{C}(\square), 40^{\circ} \mathrm{C}$ $(\bigcirc), 70^{\circ} \mathrm{C}(\triangle)$, and $100^{\circ} \mathrm{C}(\times)$.

is the irradiation light intensity, $\varepsilon_{\mathbf{A}}$ is molar extinction coefficient of $A$ at the irradiation wavelength of $366 \mathrm{~nm}$, $C_{0}$ is the total concentration $\left(C_{\mathrm{A}}(t)+C_{\mathrm{B}}(t)\right)$, and $C_{\mathrm{B}}(\infty)$ is the equilibrium concentration of B. ${ }^{15}$

Absorption changes at $572-576 \mathrm{~nm}$, where the closedring isomer has absorption maximum, in film samples of polymers by irradiation with $366 \mathrm{~nm}$ light were measured at $10-130^{\circ} \mathrm{C}$. Typical plots according to eq 3 for 13C measured at $25-100^{\circ} \mathrm{C}$ are shown in Figure 6. The left hand side of eq 3 increases linearly with time in the initial stage. The initial coloring rate did not depend on temperature. The coloring has no activation energy.

When the closed-ring isomer with initial concentration $C_{\mathrm{B}}^{\prime}(0)$ is irradiated with visible $(\lambda>550 \mathrm{~nm})$ light, the kinetics of the bleaching process is expressed by eq 4 :

$$
\ln \frac{\operatorname{Abs}^{\prime}(0)}{\operatorname{Abs}^{\prime}(t)}=2.303 \times 10^{3} I_{0} \varepsilon_{\mathrm{B}}^{\prime} \Phi_{\mathrm{B} \rightarrow \mathrm{A}} t
$$

where $\operatorname{Abs}^{\prime}(0)$ and $\operatorname{Abs}^{\prime}(t)$ denote absorbance at $\lambda_{\text {max }}$ for Polym. J., Vol. 30, No. 12, 1998 


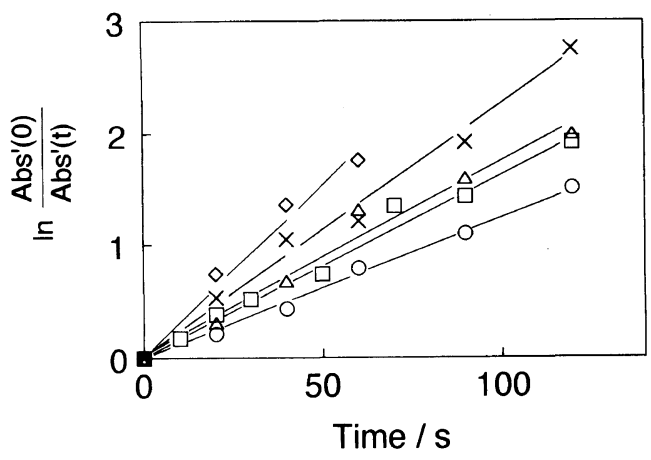

Figure 7. Irradiation time dependence of the left hand side of eq 4 in the bleaching process of polymer film sample $13 \mathrm{C}$ at $10^{\circ} \mathrm{C}(\square), 25^{\circ} \mathrm{C}$ $(\bigcirc), 40^{\circ} \mathrm{C}(\triangle), 70^{\circ} \mathrm{C}(\times)$, and $100^{\circ} \mathrm{C}(\diamond)$.

B before and under irradiation with visible $(\lambda>550 \mathrm{~nm})$ light, respectively, and $\varepsilon_{\mathrm{B}}^{\prime}$ is the molar extinction coefficient at $\lambda_{\max }$ for B. ${ }^{15}$

Absorption changes at $572-576 \mathrm{~nm}$ for the above three polymer samples by irradiation with visible $(\lambda>550$ $\mathrm{nm}$ ) light were measured at $10-130^{\circ} \mathrm{C}$. Plots according to eq 4 linearly increased with time. Figure 7 shows typical plots for $13 \mathrm{C}$ measured at $10-100^{\circ} \mathrm{C}$. The bleaching rate increases with temperature.

Conversion in the photostationary state is expressed as follows

$$
\operatorname{Conv}(C)=\frac{\varepsilon_{\mathrm{A}} \Phi_{\mathrm{A} \rightarrow \mathrm{B}}}{\varepsilon_{\mathrm{A}} \Phi_{\mathrm{A} \rightarrow \mathrm{B}}+\varepsilon_{\mathrm{B}} \Phi_{\mathrm{B} \rightarrow \mathrm{A}}} \times 100
$$

where $\varepsilon_{\mathrm{B}}$ is molar extinction coefficient of $\mathrm{B}$ at the irradiation wavelength of $366 \mathrm{~nm}$. When the bleaching quantum yield increases with temperature, the conversion should decrease. However, the conversion of $13 \mathrm{C}$ increased with temperature above $T_{\mathrm{g}}$ as shown in Figure 3. This anomalous behavior is explained as follows. In polymer films, DE has two conformations, non-reactive parallel and reactive anti-parallel, and the mutual transformation between them is prohibited below $T_{\mathrm{g}}$. The cyclization quantum yields in the initial stage as shown in Figure 6 reflect the reactivity of DEs in the anti-parallel conformation, while in the photostationary state above
$T_{\mathrm{g}}$ the transformation efficiency from the parallel to the anti-parallel conformation also contributes to the quantum yields. The ultimate conversion in the photostationary state is expected to increase when DEs in the non-reactive parallel conformation transform to the reactive anti-parallel conformation. The activation energy of bleaching in PPMA was lowest $\left(1.5 \mathrm{kcal} \mathrm{mol}^{-1}\right)$ among the three samples (PS, $3.4 \mathrm{kcal} \mathrm{mol}^{-1}$; PEMA, $2.4 \mathrm{kcal} \mathrm{mol}^{-1}$ ). Both low activation energy and efficient transformation in the two conformations are considered to cause photostationary conversion to increase above $T_{\mathrm{g}}$ in PPMA. In PS and PEMA increase in bleaching quantum yields is considered to be cancelled out by conformational transformation, and appreciable temperature dependence of the photostationary conversion above $T_{\mathrm{g}}$ was not observed.

\section{REFERENCES}

1. (a) M. Irie and K. Uchida, Bull. Chem. Soc. Jpn., 71, 985 (1998) (b) M. Irie, "Photo-reactive Materials for Ultrahigh Density Optical Memory," M. Irie, Ed., Elsevier, Amsterdam 1994, p 1.

2. B. L. Feringa, W. F. Jager, and B. de Lange, Tetrahedron, 49, 8267 (1993).

3. F. Tatezono, T. Harada, Y. Shimizu, M. Ohara, and M. Irie, Jpn. J. Appl. Phys., 32, 3987 (1993).

4. F. Ebisawa, M. Hoshino, and K. Sukegawa, Appl. Phys. Lett., 65, 2919 (1994)

5. N. Tanio and M. Irie, Jpn. J. Appl. Phys., 33, 1550 (1994).

6. T. Tsujioka, Y. Shimizu, and M. Irie, Jpn. J. Appl. Phys., 33, 1914 (1994).

7. N. Tanio and M. Irie, Jpn. J. Appl. Phys., 33, 3942 (1994).

8. T. Tsujioka, F. Tatezono, T. Harada, K. Kuroki, and M. Irie, Jpn. J. Appl. Phys., 33, 5788 (1994).

9. T. Tsujioka, M. Kume, and M. Irie, Jpn. J. Appl. Phys., 34, 6439 (1995).

10. S. Z. Janicki and G. B. Schuster, J. Am. Chem. Soc., 117, 8524 (1995).

11. T. Tsujioka, M. Kume, and M. Irie, J. Photochem. Photobiol. A: Chemistry, 104, 203 (1997).

12. G. Smets, Adv. Polym. Sci., 50, 17 (1983).

13. K. Horie and I. Mita, Adv. Polym. Sci., 88, 77 (1989).

14. I. Mita, K. Horie, and K. Hirao, Macromolecules, 22, 558 (1989).

15. H. Nakashima and M. Irie, Macromol. Chem. Phys., submitted (1998).

16. C. G. Scouten and H. C. Brown, J. Org. Chem., 38, 4092 (1973). 